\title{
Food safety knowledge of food handlers working in hotel kitchens in Turkey
}

\section{Taner Tuncer ${ }^{1} \mathbb{D}$, Aylin Akoğlu²}

Cite this article as:

Tuncer, A., Akoğlu, A. 2020). Food safety knowledge of food handlers working in hotel kitchens in Turkey. Food and Health, 6(2),77-89. https://doi.org/10.3153/FH20009

\author{
${ }^{1}$ Ağrı İbrahim Çeçen University, \\ Doğubayazit Ahmed-i Vocational \\ School, Department of Hotel, \\ Restaurant and Catering Service, Ağrı, \\ Turkey \\ 2 Abant Izzet Baysal University, Faculty \\ of Health Sciences, Department of \\ Nutrition and Dietetics, Bolu, Turkey
}

ORCID IDs of the authors:

T.A. 0000-0002-9405-0361

A.A. $0000-0002-0136-4928$

Submitted: 06.09.2019

Revision requested: 10.11 .2019

Last revision received: 15.11 .2019

Accepted: 17.11.2019

Published online: 08.01 .2020

Correspondence: Aylin AKOĞLU

E-mail: aylinakoglu@ibu.edu.tr

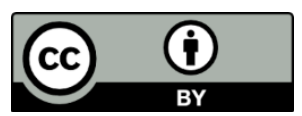

CCopyright 2020 by ScientificWebJournals Available online at

http://jfhs.scientificwebjournals.com

\begin{abstract}
This study was aimed to examine the food safety knowledge of food handlers in hotels' kitchen, to determine existing knowledge gaps in food safety, and to examine relationship between food safety knowledge and some sample characteristics such as gender, age, education level, professional experience, and past attendance to food safety training course. A total of 378 food handlers working in hotel kitchens, located at six different cities in Turkey, participated in the cross-sectional study. The food safety knowledge score of participants was average with $53.70 \%$. Knowledge scores related the different food safety aspects including personal hygiene $(53.60 \%)$, food hygiene $(53.91 \%)$, cross contamination $(61.13 \%)$, health problems that would affect food safety $(52.14 \%)$, symptoms of foodborne illnesses $(52.00 \%)$, HACCP $(51.00 \%)$ and food allergy $(50.89 \%)$ were found average level. The most striking result of this study is that although the number of employees receiving food safety training is considerably high (82.3\%), the food safety knowledge score was found less than expected. When viewed from this aspect, this work is remarkable about examining into content and adequacy of food safety training in Turkey.
\end{abstract}

Keywords: Food safety, Hotels kitchen, Food handlers, Knowledge, Turkey 


\section{Introduction}

Recent studies show that foodborne illnesses affect more than one-third of the total population in developing countries (Sani and Siow, 2014). Several foodborne illness outbreaks are associated with various factors, with the most common being food personnel's poor hygiene (Pichler et al., 2014). Presence of pathogenic microorganisms on food handlers' hands contributes to the existence of those illnesses (Egan et al., 2007; Rebouças et al., 2017). The Centre for Disease Control and Prevention (CDC) has reported that food handlers cause as much as $20 \%$ of food-related infections (Assefa et al., 2015). Furthermore, the mishandling of food seems the source of $97 \%$ of all foodborne illnesses spread through catering outlets (Egan et al., 2007). Inconvenient practices which are responsible for foodborne microbial illnesses are cross-contamination of raw and cooked foodstuffs, inadequate cooking or reheating of foods, usage of unsafe ingredients, storing food at incorrect temperatures, and cooling food inappropriately (Egan et al., 2007; Webb and Morancie, 2015). All of these factors are generally associated with a low level of knowledge and practices (Webb and Morancie, 2015). Lack of knowledge about food safety of food handlers contributes to the spread of those pathogens during food processing (Pichler et al., 2014). Thus, increase the comprehensive knowledge of food handlers about food safety and the efficient application of current information in food processing are crucial to maintaining safe food production (Bolton et al., 2008). Many studies have been conducted about the food safety knowledge of food handlers in different countries so far, for instance Brazil (Rebouças et al., 2017; Soares et al., 2012), Malaysia (Sani and Siow, 2014), Vietnam (Samapundo et al., 2016), Ghana (Kunadu et al., 2016), Jordan (Osaili et al., 2017; 2018) and Turkey (Baş et al., 2006; Tokuç et al., 2009). In many of these studies' results show that participants had limited knowledge about food safety.

Food that consumed at food and beverage establishments have been continuing to be a significant source of foodborne illnesses. The eating habit of many people have changed especially in large cities, therefore the safety of food is extremely important for trade success of food businesses. As individuals continue to become busier, the number of people eating outside is expected to continue to increase (Choi and Rajagopal, 2013). According to the report of the European Food Safety Authority (EFSA) and the European Centre for Disease Prevention and Control, about twenty-five percent of the foodborne epidemy, occurred in European Union countries, had been found associated with restaurants, cafes, pubs, and hotels (ECDC - European Food Safety Authority and European Centre for Disease Prevention and Control, 2017). Similarly, catering services has also a critical role in the spread of those infections. In the USA, Europe, and Ireland those had been partially traced to catering establishments (approximately $45 \%, 22 \%$, and 50\% respectively) (Giritlioglu et al., 2011).

Hotels, as an important part of the tourism industry, are one of the most common food production places. Hence, food safety, hygiene, and sanitation are the most critical issues need to be considered by hotel management. If the importance that required is not given to those issues during the preparation and service of the food, it might cause to the health threat for both personnel and customers (Baser et al., 2017). Bolton et al. (2008) stated that the food preparation personnel, and also customers may seriously be affected by the improper hygienic conditions in the hotel kitchens. In Turkey, there were some regional studies had been made for the evaluation of the food safety knowledge of food handlers working in hotel kitchens (Baş et al., 2006; Sanlier et al., 2010; Baser et al., 2017). However, there is no comprehensive study that includes the whole country. The current study aims to examine the food safety knowledge of food handlers working in hotels' kitchen in different cities of Turkey.

\section{Materials and Methods}

\section{Research Design and Participants}

A cross-sectional study had been made between May 2017 and September 2017 and involved 378 food handlers working in 22 different food establishments, as a participant. Assessments are comprised of four- and five-star hotels' kitchens in the following cities of Turkey: Ankara, İstanbul, Muğla, Hatay, Diyarbakır, and Nevşehir. The reason why the provinces mentioned in the research are selected as sample was related to the high number of city hotels in these provinces. Since the universe size could not be calculated exactly, the sample size scale table (Yazıcıoğlu and Erdoğan, 2004) was used for determining the sample size. In cases where the universe is 1.000 .000 and above, the sample size was considered as min 323 , so the 378 sample size reached in this study was sufficient. In sampling, simple random sampling was used in which each element of the universe had equal chance of entering the sample (Arlkan, 2004). After the implementation of questionnaires, face-to-face interviews were performed to guarantee the accuracy of responses which had given to survey questions. Participants were given an ample amount of time ( $\sim 30 \mathrm{~min})$ to answer the questionnaire.

\section{Questionnaire Design}

The questionnaire was prepared from previously performed studies Baş et al., 2006; Giritlioglu et al., 2011; Osaili et al., 2011; Panchal et al., 2014; Shafie and Azman, 2015; Smigic et al., 2016). The questionnaire's reliability was tested via 
Cronbach alpha test, with a reliability coefficient of 0.913 (Santos, 1999). In the first part of the questionnaire, some characteristics of subjects were collected such as gender, age, education level, professional experience, past attendance to food safety training courses, the habit of updating knowledge and self-confidence situation about food safety, and the kind of and location of their workplace (hotel). Second part included 65 questions that examined respondents' knowledge of personal hygiene (5 items), cross-contamination ( 8 items), food hygiene (23 items), health problems that would affect food safety ( 7 items), symptoms of foodborne diseases ( 7 items), knowledge of HACCP (Hazard Analysis Critical Control Points) (6 items) and food allergy (9 items) issues. Each question consisted of three optional answers of "yes", "no" and "do not know" in order to reduce the probability of respondents in selecting the correct answer by chance.

\section{Data Analysis}

All statistical analyses were performed using the Statistical Package for the Social Sciences, Version 16.0 (SPSS, Inc., Chicago, IL, USA). Descriptive statistics were calculated for all variables. Food safety knowledge scores were analyzed by using an independent sample t-test for two groups or Analysis of Variance (ANOVA) with post-hoc Duncan test for more than two groups. $p<0.05$ were considered to be statistically significant. The total food safety knowledge score of respondents' was calculated by summation of the correct answers of the 65 questions included in the seven categories (maximum score is 65). Each correct answer was given 1 point but the incorrect or not sure answer was given 0 points (Osaili et al., 2017). Additionally, the score was converted to a percentage by dividing the total score by the maximum score accessible (score/maximum score*100) and a randomized scoring system was used to assess the level of knowledge (Shafie and Azman, 2015). As per that scoring system, the score that lower than $50 \%$ was considered as "poor knowledge', the score between $50 \%$ and $75 \%$ was considered as 'average knowledge' and the score that higher than 75\% was considered as 'excellent knowledge' (Samapundo et al., 2016).

\section{Results and Discussion}

\section{Sample Characteristics}

Characteristics of the participants were shown in Table 1 . The vast majority of the participants were men (72.2\%). In the previous studies, it was mentioned that there were many female kitchen employees in Turkey (Baş et al., 2006; Çakıroğlu and Uçar, 2008). This is because of cultural conditions in Turkey where females do not prefer to work in the hotels' kitchen. Almost half of the participants (53.4\%) were between the age ranges $21-30$. The total of $79.3 \%$ of all participants had finished elementary and high school, whereas $14.0 \%$ had a bachelor degree. The number of food handlers who have baccalaureate is very low in Turkey and the findings of the current study are consistent with that level of education. Regarding professional experience in the food services, $20.1 \%$ of all participants had $<1$ year, $40.3 \%$ of them had between 1 year and 3 years, $18.3 \%$ of them had between 4 years and 6 years of and $21.2 \%$ of them had more than 7 years' work experience. About $82.3 \%$ of the participants reported that they were previously attended to training courses about food safety. About three of four all participants stated that they had a habit of following new information (77.2\%) and feel confident (79.4\%) about food safety. A lot of participants $(43.9 \%)$ have also reported using the internet to follow new information about food safety.

\section{Results of Knowledge Scores in Relation to Sample Characteristics}

There were a significant association between food handlers' knowledge and the variables such as their gender $(\mathrm{p}=0.000)$, age $(p=0.000)$, professional experience $(p=0.000)$, past attendance to food safety training course $(p=0.000)$, the type $(\mathrm{p}=0.000)$ and location $(\mathrm{p}=0.000)$ of their workplaces, the habit of updating information $(\mathrm{p}=0.000)$, and confidence about food safety $(\mathrm{p}=0.001)$. Male participants' knowledge score (35.95) was significantly higher than the female's (32.30) $(p<0.05)$. Similarly, it was also determined by Çakıroğlu and Uçar (2008) that the different was significant between knowledge scores about kitchen and equipment hygiene from the aspect of gender. Nevertheless, unlike our study, it was also mentioned that knowledge scores of female employees about general hygiene were higher than male employees. On the other hand, Şanlier et al. (2010) reported that there the different was insignificant $(p>0.05)$ between genders in their study, which had investigated food safety knowledge levels of food handlers in the hotels' kitchen. Even though the different was found insignificant $(p>0.05)$ amongst participants with regards to education levels, knowledge score of high school graduates (36.49) who are nearly half of the participants $(48.9 \%)$ was slightly higher than the others. Unlike our study, the different was found significant $(p<0.05)$ between general hygiene konowledge and education status in another study (Şanlıer et al., 2010). The participants who both older than 40 years and the occupational experience longer than 7 years were achieved a higher knowledge score by far (43.15 and 44.60, respectively) $(p<0.05)$. Likewise, Şanlıer et al. (2010) had also pointed out the higher score of those who have had 16 years or more experience about general hygiene in their study. Additionally, 
Martins et al. (2012) reported that the knowledge scores increase through age and experience. Results of those studies are concordant with our study and show a positive influence of age and experience on food safety knowledge. The food preparers' knowledge score (36.36) who had received food safety training course $(82.3 \%)$ were significantly higher than those who had not $(28.32 \%)(p<0.05)$. Many studies have been declared that the most important component for ensuring food safety was a knowledge. Hence, education and training about food safety have been emphasized on various other studies as a must for prevention of foodborne diseases (Ajala et al., 2010; Choi and Rajagopal, 2013; Mullan et al., 2013; Shafie and Azman, 2015). In terms of hotel types, the knowledge score of food handlers working in five-star hotels (39.72) was significantly higher than those working in the four-star hotels $(27.90)(p<0.05)$. Moreover, the knowledge score of food preparers working in hotels in different cities had remarkably varied $(p<0.05)$. Those who constantly update their information and declared their self-confidence about food safety have had significantly higher knowledge score than the others $(p<0.05)$.

Table 1. Characteristics of food handlers and differences in the food safety knowledge scores

\begin{tabular}{|c|c|c|c|c|c|c|}
\hline & & $\mathbf{n}$ & $\%$ & $\begin{array}{c}\text { Mean } \\
\text { (Knowledge Score) }\end{array}$ & Score percent & $\begin{array}{l}\text { Within } \\
\text { p-value }\end{array}$ \\
\hline & Total & 378 & 100 & 34.91 & 53.70 & \\
\hline \multirow{2}{*}{ Gender } & Male & 273 & 72.2 & 35.95 & 55.31 & 0.000 \\
\hline & Female & 105 & 27.8 & 32.3 & 49.69 & \\
\hline \multirow{6}{*}{ Age } & $15-19$ & 27 & 7.1 & 37.14 & 57.14 & 0.000 \\
\hline & $20-24$ & 89 & 23.5 & 32.15 & 49.46 & \\
\hline & $25-29$ & 113 & 29.9 & 33.18 & 51.05 & \\
\hline & $30-34$ & 82 & 21.7 & 35.56 & 54.71 & \\
\hline & $35-39$ & 27 & 7.1 & 34.00 & 52.31 & \\
\hline & $\geq 40$ & 40 & 10.6 & 43.15 & 66.38 & \\
\hline \multirow{6}{*}{ Education Level } & Literate & 25 & 6.6 & 32.04 & 49.29 & 0.197 \\
\hline & Elementary school & 115 & 30.4 & 33.24 & 51.14 & \\
\hline & High school & 185 & 48.9 & 36.49 & 56.14 & \\
\hline & Two-year degree & 30 & 7.9 & 36.03 & 55.43 & \\
\hline & Undergraduate & 22 & 5.8 & 32.77 & 50.42 & \\
\hline & Post graduate & 1 & 0.3 & 31.00 & 47.69 & \\
\hline \multirow{4}{*}{ Professional experience } & $<1$ year & 76 & 20.1 & 28.42 & 43.72 & 0.000 \\
\hline & $1-3$ years & 153 & 40.5 & 31.11 & 47.86 & \\
\hline & 4-6 years & 69 & 18.3 & 39.42 & 60.65 & \\
\hline & $\geq 7$ years & 80 & 21.2 & 44.60 & 68.62 & \\
\hline \multirow{2}{*}{$\begin{array}{l}\text { Past attendance to food } \\
\text { safety training course }\end{array}$} & Yes & 311 & 82.3 & 36.36 & 55.94 & 0.000 \\
\hline & No & 67 & 17.7 & 28.32 & 43.57 & \\
\hline \multirow{2}{*}{ Type of hotel } & Five-star hotel & 153 & 40.5 & 39.72 & 61.11 & 0.000 \\
\hline & Four-star hotel & 225 & 59.5 & 27.90 & 42.92 & \\
\hline \multirow{6}{*}{ Location of hotel } & Ankara & 71 & 18.8 & 25.66 & 39.48 & 0.000 \\
\hline & Diyarbakır & 75 & 19.8 & 55.05 & 84.69 & \\
\hline & Hatay & 39 & 10.3 & 36.87 & 56.72 & \\
\hline & İstanbul & 81 & 21.4 & 25.48 & 39.20 & \\
\hline & Muğla & 92 & 24.3 & 30.71 & 47.25 & \\
\hline & Nevşehir & 20 & 5.3 & 46.45 & 71.46 & \\
\hline \multirow{6}{*}{$\begin{array}{l}\text { The habit of following } \\
\text { new information about } \\
\text { food safety }\end{array}$} & Yes & 292 & 77.2 & & & 0.000 \\
\hline & - Book/Magazine & 29 & 7.7 & & & \\
\hline & $\begin{array}{l}\text { - Television pro- } \\
\text { grams }\end{array}$ & 88 & 23.3 & 36.27 & 55.80 & \\
\hline & - Internet & 166 & 43.9 & & & \\
\hline & - Others & 9 & 2.4 & & & \\
\hline & No & 86 & 22.8 & 30.40 & 46.77 & \\
\hline \multirow{2}{*}{$\begin{array}{l}\text { Self-confident in food } \\
\text { safety }\end{array}$} & Yes & 300 & 79.4 & 36.06 & 56.15 & 0.001 \\
\hline & No & 78 & 20.6 & 30.64 & 45.08 & \\
\hline
\end{tabular}




\section{Total Food Safety Knowledge Score}

The knowledge scores related to different food safety areas and the total knowledge status were evaluated according to the percentile score (arbitrary scoring system). The total knowledge score of participants was $53.70 \%(34.91 / 65)$ as shown in Table 2. This result indicated that food handlers working in hotels' kitchen had average knowledge about food safety. The total knowledge score reported in this study was found better than $43.4 \%$ as reported in Turkey (Baş et al. 2006 ) and $46 \%$ as reported in small and micro enterprises in South Africa (Cape et al., 2007) for food handlers. Nevertheless, our results on total knowledge of food safety was found quite lower than the studies of Pichler et al. (2014), Osaili et al. (2013), Osaili et al. (2018), Panchal et al. (2014), GomesNeves et al. (2007), Martins et al. (2012) and which had been found that score as $76 \%, 69.4 \%, 67.1 \%, 65 \%, 62.9 \%, 56 \%$, respectively. We were expected from participants to receive relatively higher scores in food safety knowledge due to the majority of them had reported that they attended a training course about food safety (82.3\%). From this point of view, the result has shown that food safety training is not sufficient alone to have knowledge about it. That result might be related to the quality of the training. Food safety educations should be repeated intermittently, their contents should be updated and its competence should be measured by conducting posttraining applications and exams.

In general, knowledge score that involved to the different sections of food safety, like personal hygiene $(53.60 \%)$, cross- contamination $(61.13 \%)$, food hygiene $(53.91 \%)$, health problems which may affect food safety $(52.14 \%)$, symptoms of foodborne diseases $(52.00 \%)$, HACCP $(51.00 \%)$ and food allergy $(50.89 \%)$ was average level. The highest percentage of correct answers belonged to "knowledge of cross-contamination" (61.13\%), while the lowest one belonged "knowledge of food allergy" (50.89\%). Food allergy is a more recent issue than the other aspects and it is just mentioned as the subject of food safety training. For that reason, it seemed quite normal to get a lower score. As a result of our study, the knowledge score of personal hygiene (53.60\%) was found immensely higher than those in the reports of Martins et al. (2012) and Baş et al. (2006), 51.5\% and 31.8\%, respectively. Similarly, the knowledge score of cross-contamination in our study $(61.30 \%)$ was extremely higher than the score calculated both for food handlers at the main campus of University Kebangsaan Malaysia, which reported by Sani and Slow (2014) (44.6\%), and at Residential Colleges and Canteen in Malaysia, which reported by Nee and Sani (2011) $(46.9 \%)$.

\section{Food Safety Knowledge Related to Different Food Safety Areas}

Food safety knowledge related to different food safety areas was examined individually and determined some food safety gaps in these areas. All data related to this section are shown in Table 3.

Table 2. Knowledge scores (mean and percentage) related to different food safety areas and total knowledge scores for food handlers in a hotel kitchen in Turkey

\begin{tabular}{cccc}
\hline Food safety areas & Mean & $\begin{array}{c}\text { The possible } \\
\text { range of scores }\end{array}$ & Score percent \\
\hline Personal hygiene & 2.68 & $0-5$ & 53.60 \\
Cross contamination & 4.89 & $0-8$ & 61.13 \\
Health problems that would af- & 3.65 & $0-7$ & 52.14 \\
fect food safety & 3.64 & $0-7$ & 52.00 \\
Symptoms of foodborne illnesses & 12.40 & $0-23$ & 53.91 \\
Food hygiene & 3.06 & $0-6$ & 51.00 \\
HACCP & 4.58 & $0-9$ & 50.89 \\
Food allergy & 34.91 & $0-65$ & 53.70 \\
\hline
\end{tabular}


Table 3. Percentage (\%) of correct answers for each question

\begin{tabular}{|c|c|c|}
\hline \multirow[b]{2}{*}{ Health problems would affect food safety } & \multicolumn{2}{|c|}{$\begin{array}{l}\text { Correct an- } \\
\text { swer }\end{array}$} \\
\hline & $\mathbf{n}$ & $\%$ \\
\hline Sneezing would affect food safety & 196 & 51.90 \\
\hline Hypertension would affect food safety & 202 & 53.40 \\
\hline Diarrhea would affect food safety & 179 & 47.40 \\
\hline Flu would affect food safety & 212 & 56.10 \\
\hline Fever would affect food safety & 217 & 57.40 \\
\hline Smoking would affect food safety & 205 & 54.20 \\
\hline Covered wound in the hand with wearing a glove would affect food safety & 172 & 45.50 \\
\hline Symptoms of foodborne illness & $\mathbf{n}$ & $\%$ \\
\hline Hypertension is a symptom of foodborne illnesses & 135 & 35.70 \\
\hline Diarrhea is a symptom of foodborne illnesses & 227 & 60.10 \\
\hline Nausea is a symptom of foodborne illnesses & 206 & 54.50 \\
\hline Vomiting is a symptom of foodborne illnesses & 201 & 53.20 \\
\hline Pain in the bone is a symptom of foodborne illnesses & 199 & 52.60 \\
\hline Bacteria is the only cause of foodborne diseases & 190 & 50.30 \\
\hline Pathogens in food can cause diseases and even death & 220 & 58.20 \\
\hline Personal hygiene & $\mathbf{n}$ & $\%$ \\
\hline Duration of hand washing $\geq 20 \mathrm{~s}$ & 206 & 54.50 \\
\hline Washing hands after touching money & 215 & 56.90 \\
\hline Washing hands after handling raw meats or poultry & 191 & 50.50 \\
\hline Washing hands before preparing meals & 200 & 52.90 \\
\hline $\begin{array}{l}\text { Food-services staff with abrasion or cuts on fingers or hands should not touch un- } \\
\text { wrapped foods }\end{array}$ & 202 & 53.40 \\
\hline Cross contamination & $\mathbf{n}$ & $\%$ \\
\hline Use same cutting board to cut raw meat or poultry and to chop vegetables & 231 & 61.10 \\
\hline Use same knife to cut raw meat or poultry and to chop vegetables & 254 & 67.20 \\
\hline $\begin{array}{l}\text { Wash cutting board used to cut raw meat or poultry with cold water before using it to } \\
\text { chop vegetables }\end{array}$ & 227 & 60.10 \\
\hline $\begin{array}{l}\text { Store vegetables salad in the lower shelf in refrigerator if raw meat or chicken in the } \\
\text { middle shelf }\end{array}$ & 258 & 31.70 \\
\hline Store vegetables salad in meat or poultry refrigerator & 234 & 61.90 \\
\hline $\begin{array}{l}\text { Wash knife used to cut raw meat or poultry with water and soap then apply sani- } \\
\text { tizer before using it to chop vegetables }\end{array}$ & 201 & 53.20 \\
\hline $\begin{array}{l}\text { Wash knife used to cut raw meat or poultry with cold water before using it to chop vege- } \\
\text { tables }\end{array}$ & 239 & 63.20 \\
\hline $\begin{array}{l}\text { Use cap, masks, protective gloves, and adequate clothing reduces the risk of food } \\
\text { contamination }\end{array}$ & 206 & 54.50 \\
\hline
\end{tabular}

*Sentences in bold indicate the correct expressions. 
Table 3 continues. Percentage $(\%)$ of correct answers for each question

Food hygiene (safe temperatures, purchasing, storage, thawing, cooking and reheating of the foods)

$5^{\circ} \mathrm{C}$ is known as minimum temperature danger zone

Refrigerator operating temperature is $1-5{ }^{\circ} \mathrm{C}$

Freezer operating temperature is $-18^{\circ} \mathrm{C}$

Reheat food to temperature of $74^{\circ} \mathrm{C}$

$202 \quad 53.40$

Hot food needs to be kept and served at $60^{\circ} \mathrm{C}$ or hotter

$202 \quad 53.40$

Cracked, dirty, broken eggs should not be purchased

17847.10

Damaged and swollen cans should not be purchased

$208 \quad 55.00$

Conserving cooked food and raw food together causes foodborne illness

$199 \quad 52.60$

Store leftover in the refrigerator

$234 \quad 61.90$

Store leftover on the countertop or table in the kitchen

$201 \quad 53.20$

Store leftover in the oven

24965.90

Frozen foods should be stored in their own packages

$215 \quad 56.90$

The total time in the temperature danger zone must not be longer than 4 hours $225 \quad 59.50$

Thaw frozen raw meat or poultry on the kitchen counter in an open container

$230 \quad 60.80$

Thaw frozen raw meat or poultry in the refrigerator

$206 \quad 54.50$

Thaw frozen raw meat or poultry in running tap water

$205 \quad 54.20$

Thaw frozen raw meat or poultry in the microwave

$110 \quad 29.10$

Thaw frozen raw meat or poultry on the kitchen counter in a covered container.

18548.90

It is necessary to check thermometer settings of refrigerators, freezers and store at least twice a day

Improper heating of food causes foodborne illnesses

21155.80

Check poultry is sufficiently cooked by thermometer

$206 \quad 54.50$

It is perfectly safe to consume food that tastes and smells normal

$202 \quad 53.40$

Food should be served no later than two hours after preparation

\begin{tabular}{|c|c|c|}
\hline Food should be served no later than two hours after preparation & 221 & 58.50 \\
\hline НАCCP & $\mathbf{n}$ & $\%$ \\
\hline HACCP is an international food safety system & 208 & 55.00 \\
\hline HACCP is a preventive system that ensures food safety in all stages of food production & 203 & 53.70 \\
\hline HACCP is a mandatory system in Turkey's food law & 184 & 48.70 \\
\hline The HACCP system requires staff training in hygiene & 191 & 50.50 \\
\hline Microbiological hazards cannot be included in HACCP & 161 & 42.60 \\
\hline HACCP is not a very effective system to provide food safety & 211 & 55.80 \\
\hline Food allergy & $\mathbf{n}$ & $\%$ \\
\hline A food allergy is an abnormal response of the immune system to an ordinarily harmless food & 202 & 53.40 \\
\hline Food allergy can result in death & 214 & 56.60 \\
\hline Customers with food allergies can safely consume a small amount of that food & 157 & 41.50 \\
\hline Eczema can be a symptom of food allergy & 133 & 35.20 \\
\hline Asthma can be a symptom of food allergy & 198 & 52.40 \\
\hline Food additives may cause an allergic reaction & 204 & 54.00 \\
\hline Peanut is one of the major foods that cause serious allergic reactions & 205 & 54.20 \\
\hline Labels on food give information about allergic content & 203 & 53.70 \\
\hline Food-allergic reactions occur within from $2 \mathrm{~min}$ to $12 \mathrm{~h}$ after ingestion & 219 & 57.90 \\
\hline
\end{tabular}

*Sentences in bold indicate the correct expressions. 


\section{Health Problems Would Affect Food Safety}

Infected food handlers might contaminate foods and surfaces, thus, leading to spreading foodborne diseases (Todd et al., 2008). For that reason, having knowledge about health problems that would affect food safety has become a considerable aspect. The percentages of participants who knew that sneezing, diarrhea, flu, fever, and smoking would affect food safety during food processing were $51.9 \%, 47.40 \%, 56.10 \%$, $57.40 \%, 54.20 \%$, respectively. On the other hand, even though that is not scientifically relevant, almost $53.40 \%$ of participants were believed that hypertension would affect food safety. Less than $50 \%$ of them thought that wearing a glove with a covered wound on their hand would affect food safety. The data obtained from our study indicated that about half of the participants were not aware of 'health problems would affect food safety'. As higher than ours, Osaili et al. (2017) have reported that more than $70 \%$ of the food service staff, working in hospitals in Jordan were known that sneezing, fever, diarrhea, and smoking during working hours had an impact on food safety. However, there are also studies which have lower results than the current one such as the reports of Jianu and Chis (2012) that mentioned only 31\% of the food handlers in Western Romania had knowledge about coughing and/or sneezing might have an effect on food contamination.

\section{Symptoms of Foodborne Illness}

When people suffer from food poisoning they cannot be able to understand it is related to food unless they have poor or no knowledge about symptoms of foodborne illnesses. This condition increases the contamination risk since infected food handlers can contaminate food, surface, and other workers (Todd et al., 2008). The most common symptoms of foodborne diseases were reported as diarrhea, nausea, vomiting, and stomach cramps (CDC, 2018). In the current study, more than half of the participants knew that diarrhea $(60.10 \%)$, nausea $(54.50 \%)$ and vomiting $(53.20 \%)$ are the typical symptoms of foodborne illnesses. Although this result showed that the relevant knowledge level is at a moderate level, it is unfortunate that it is a very low rate compared to other studies. For instance, in contrast to that result, Osaili et al. $(2013,2017)$ reported that $90 \%$ of foodservice staff working in the hospitals and restaurants had knowledge about the most common symptoms of foodborne diseases such as diarrhea, vomiting, abdominal pain, and nausea. Similarly, Jianu and Chis (2012) were pointed out that most of the food handlers $(77 \%)$ in Western Romania could explain these symptoms. Diarrhea, in general, is defined as the most common symptom of those infections in many studies [Tokuç et al., 2009; Osaili et al., 2013, 2017); because of being the most emphasized one in the media (Osaili et al., 2017). Hypertension and bone pain are not symptoms of foodborne diseases. Amongst participants, $35.7 \%$ of them knew that that statement was not correct for hypertension and $52.60 \%$ knew that was not correct for bone pain. Similarly, in the study of Osaili et al. (2017), in which less than $42 \%$ of the participants assumed that hypertension and bone pain were symptoms of foodborne diseases.

\section{Personal Hygiene}

Hygienic practices in the responsibility of food handlers are considered as the most effective method to reduce food contamination risk in food establishments. Amidst these hygienic practices, hand hygiene is a more effective method for preventing foodborne diseases when compared with the cleaning and disinfection of surfaces that contact food (Todd et al., 2007). As a matter of fact, it is crucial to have sufficient knowledge about handwashing and concerned staff should pay more attention to this issue. In the current study, the knowledge about the handwashing of employees was determined and the correct response rate was around 50\% and this result was quite low compared to other studies (Osaili et al., 2013, 2017). Similar to our finding, Tan et al. (2013) and Rebouças et al. (2017) showed that the majority of food handlers had inadequate knowledge about handwashing. On the other hand, "Duration of handwashing must be minimum $20 \mathrm{sec} . "$ statement was correctly identified as true by $54.50 \%$ of attendees. When it comes to practice, the time of handwashing is usually shorter than required and not correctly performing by the employees. Although, it is a good result that more than half of the attendees responded correctly to this statement. Unlike our results, Debess et al. (2009), Osaili et al. (2017) and Osaili et al. (2018) reported that only $39 \%, 29.5 \%$, and $31.9 \%$ knew the time that should be spent during hand washing, respectively.

\section{Cross Contamination}

Cross-contamination is one of the most contributory risk factors related to foodborne diseases. Cross-contamination and contaminated equipment are referred to as risk factors in England and Wales $(25 \%)$, and in the US $(26 \%)$ of general epidemics, respectively. In the catering industry, it was well known that cross-contamination of food via receptacles, hands and surfaces were major risk factors (Bolton et al., 2008). Therefore cleaning those surfaces and equipment is essential to prevent cross-contamination. Over $60 \%$ of participants answered "Use the same cutting board to cut raw meat or poultry and to chop vegetables" and "Use the same knife to cut raw meat or poultry and to chop vegetables" statements correctly. $53.20 \%$ of participants correctly knew the procedures for cleaning and sanitizing containers. Previous studies 
have reported better knowledge level about sanitization procedures of equipment and surfaces than reported in the current one (Tokuçet al., 2009; Jianu and Chiş, 2012; Osaili et al., 2013).

The number of those who knew that raw meat and vegetables must not be chopped on the same cutting board (61.1\%) and knew to must change the knife to cut raw meat or poultry and to chop vegetables (67.20\%) was substantially high. Pieces of equipment, especially cutting boards have a crucial role with respect to cross-contamination. It was found that more than $50 \%$ of selected cutting boards used in hotels in Spain had been contaminated with superfluous levels of microorganisms (Doménech-Sánchez et al., 2011). The number of correct responses given to questions about cross-contamination is higher than in the other food safety areas in the current study, even though this rate is still unsatisfactory and there is still a high risk of cross-contamination. Similarly, in another study which made by Bolton et al. (2008) with 200 chefs and managers of restaurants in Ireland, the risk of cross-contamination sourced from the tools and surfaces were determined as high in kitchens of restaurants. Taking necessary precautions by food handlers such as the hygiene of their hands, bodies, and items of clothing, equipment, and workplace will help to lessen the incidence of cross-contamination (Assefa et al., 2015).

\section{Food Hygiene (Safe Temperatures, Purchasing, Storage, Thawing, Cooking and Reheating of the Foods)}

Foodborne diseases have been associated with improper storage, thawing, cooking or reheating of the food and those are frequently due to a lack of awareness or applications about food hygiene. In the current study, the rate of correct answers to statements about this food safety area was usually above $50 \%$. When the statements are viewed singly, it was seen that more than half of the participants $(61.9 \%)$ had correctly known how to separate raw meat from other food during storage. Unluckily, this result was found weaker than the studies of Walker et al. (2003) and Bolton et al. (2008), in which had been reported that results as $84 \%$ for the US, as $97 \%$ for the UK and as $92 \%$ for Ireland, respectively. $60.80 \%$ and $48.90 \%$ of attendees stated that they thaw frozen raw meat or poultry on the kitchen counter, sequentially the open and closed container. The distribution of participants who knew the correct thawing procedures was: $54.50 \%$ use the refrigerator and $29.10 \%$ use the microwave and $54.20 \%$ use the tap water. In some other studies, such as Osaili et al. $(2013,2017,2018)$ responses related to thawing in a microwave $(8.1 \%, 4.1 \%$, $1.1 \%$, respectively) were similarly low. These results showed that thawing in the microwave is not a common process in the hotel kitchens. About $53.40 \%$ of participants knew the right process to determine whether poultry is cooked well by using a thermometer. Unlike this study, a lower rate $(12.7 \%$ and $19.5 \%$ ) of attendees had been found correctly answered that question in the study of Osaili et al. $(2017,2018)$. The statements about correct refrigeration and freezing temperature, the reheating temperature of food and minimum danger zone were correctly answered by more than half of participants $(51.60 \%, 53.40 \%, 53.40 \%$, and $52.40 \%$, respectively). This finding showed that the majority of participants knew the correct temperature about refrigeration, freezing, reheating and the danger zone. Unlike our results, in many studies (Baş et al. (2006); Tokuç et al., (2009); Martins et al., (2012); Osaili et al., (2013); Webb and Morancie (2015); Kunadu et al., (2016); Osaili et al. (2017)), it was reported that a lack of knowledge among food service staff about critical temperatures.

One of the most common causes of foodborne diseases is inaccurate cooling of cooked food. Even if the food is safely cooked, the bacteria can be contaminated that food. For this reason, remainders must be put in shallow containers for quick cooling and refrigerated at $4{ }^{\circ} \mathrm{C}$ or below within two hours (USDA, 2017). In our study, 53.20\% and 58.50\% of participants knew that "store remainder in the fridge" and "food should be served no later than two hours after preparation", respectively. Osaili et al. (2018) reported that a small part of the participants $(15 \%)$ had known the correct retention temperature needed to eat. In contrast to Osaili et al. (2018), in our study, almost half of the attendees correctly answered this statement.

\section{HACCP}

Large establishments adopt the HACCP system unlike in the small enterprises in the catering sector. There are some obstacles in small businesses to practice the HACCP system, such as financial constraints and attitudes that restrict the process, absence of legal arrangements, lacked expertise (Egan et al., 2007). Additionally, in catering companies, supervision of the management and lack of motivation, resources and awareness about food safety are other factors that prevent the effective sustaining of the HACCP system (Osaili et al., 2018). Less than half of participants (48.70\%) knew that the system is mandatory in our country. Similar results were obtained from the study of Ulusoy and Çolakoğlu (2015) which measured the level of HACCP knowledge of food handlers in enterprises in İstanbul. In the current study, approximately half of the participants correctly responded to the statements about HACCP. Unlike our result, Bolton et al. (2008) reported that head chefs and catering managers in Ireland had inadequate knowledge about HACCP. Similarly, Rebouças et al. (2017) in their study which performed with head chefs and managers in hotels' restaurants of Salvador (Brazil), noticed 
that nearly $35.0 \%$ of the participants knew what the HACCP means.

\section{Food Allergy}

Food allergy is a prominent public health problem as well as food infections. Researchers estimate that up to 15 millions of Americans and about 17 million Europeans have food allergies (FARE, 2017; EAACI, 2017). In this point of view, food handlers might have a critical role to reduce the risk of food allergy and adverse reactions (Dupuis et al., 2016). Therefore, the level of knowledge of food handlers and behavior against food allergy reactions are very important. In the current study, it was seen that more than half of the participants responded correctly to statements such as, "food allergy is an abnormal response of the immune system to food that harmless normally" (53.40\%), "food allergy may result in death" $(56.60 \%)$, "asthma might be a symptom of food allergy" (52.40\%), "food additives may cause allergic reaction" $(54.0 \%)$ and "peanut is a significant food may cause serious allergic reactions" $(54.20 \%)$. These results showed that more than half of the participants responded correctly to expressions related to food allergy. On the contrary, $41.50 \%$ of them incorrectly declared that "customers who have a food allergy can safely consume a small amount of that food". Although food allergy is a current issue and is not frequently included in the training, it is quite a good result that attendees had accurately responded to almost $50 \%$ of the statements. The levels of food allergy knowledge and practices of food handlers had seen insufficient in many studies (Ajala et al., 2010; Choi and Rajagopal, 2013; Shafie and Azman, 2015). Food handlers are expected to increase their awareness and knowledge about food allergy since the public health authorities' more interest in food allergy over time.

\section{Conclusion}

It is provided important information and displayed many features in that study, concerning the food safety knowledge conditions of food handlers who work in kitchens of 22 hotels located at six different cities in Turkey. The results obtained from our study showed that the level of food safety knowledge of food workers in hotels' kitchens is at an average level. However, there are some significant gaps in food safety areas, such as personal hygiene, food allergy, and HACCP. The most striking result of this study is despite the high number of employees received food safety training the level of knowledge about food safety is medium. In such a group that $82.3 \%$ had received food safety training, we would expect a better level. This result may be associated with the adequacy status of food safety training in Turkey. There is a general consensus that trained food handlers are needed to prevent and control foodborne diseases. Thus, food handlers should be taken food safety training regularly. However, as shown in the current study, training is not just enough but the quality of those training should also be measured regularly, effective application of training should be provided and inspections should be made routinely. Not only food handlers, but also food manufacturers, consumers, food and beverage industrialists should take responsibility in this regard, besides that governments are primarily responsible for ensuring and maintaining food safety. Therefore, all these stakeholders should be trained about food safety and systematic control should be made by the government. This is especially important in developing countries such as Turkey, where the risk of foodborne diseases is loud. As this study comprises the employees who work in hotels located in various regions of Turkey, the obtained results can be generalized to all of the hotels in Turkey. Hence, this study is a comprehensive survey that measured the food safety knowledge level of the hotel kitchen staff in Turkey. In the future, some further studies might be performed to determine the relationship between the knowledge, attitudes, and practices of food handlers with food safety training.

\section{Compliance with Ethical Standard}

Conflict of interests: The authors declare that for this article they have no actual, potential or perceived the conflict of interests.

Funding: No financial support was received for this study.

Ethics committee approval: "Abant İzzet Baysal University Humanities Ethics Committee in Social Sciences" was received on 17.07.2017 with the document number 2017/175.

Acknowledgements: Authors are thankful for the hotel kitchen staff who participated in this research study and also for Buğra Soykut for editing the article. This study was a part of a Master Thesis of Taner Tuncer (Bolu Abant Izzet Baysal University, Department of Gastronomy and Culinary Arts).

\section{References}

Ajala, A.R., Cruz, A.G., Faria, J.A., Walter, E.H., Granato, D., Sant, A.S. (2010). Food allergens: Knowledge and practices of food handlers in restaurants. Food Control, 21(10), 1318-1321.

https://doi.org/10.1016/j.foodcont.2010.04.002

Arıkan, R. (2004). Araştırma teknikleri ve rapor hazırlama. Ankara: Asil Publishing. ISBN: 9789758784356

Assefa, T., Tasew, H., Wondafrash, B., Beker, J. (2015). Community medicine and health education assessment of bacterial hand contamination and associated factors among food handlers working in the student cafeterias of Jimma. 
Journal of Community Medicine and Health Education, 5(2), $1-8$.

https://doi.org/10.4172/2161-0711.1000345

Baser, F., Ture, H., Abubakirova, A., Sanlier, N., Cil, B. (2017). Structural modeling of the relationship among food safety knowledge, attitude and behavior of hotel staff in Turkey. Food Control, 73, 438-444.

https://doi.org/10.1016/j.foodcont.2016.08.032

Baş, M., Ersun, A.Ş., Kıvanç, G. (2006). The evaluation of food hygiene knowledge, attitudes, and practices of food handlers' in food businesses in Turkey. Food Control, 17(4), 317322.

https://doi.org/10.1016/j.foodcont.2004.11.006

Bolton, D.J., Meally, A., Blair, I.S., McDowell, D.A., Cowan, C. (2008). Food safety knowledge of head chefs and catering managers in Ireland. Food Control, 19(3), 291-300. https://doi.org/10.1016/j.foodcont.2007.04.006

Cape, W., Marais, M., Conradie, N., Labadarios, D. (2007). Small and micro enterprises-aspects of knowledge, attitudes and practices of managers' and food handlers' knowledge of food safety in the proximity of Tygerberg Academic Hospital, Western Cape. South African Journal of Clinical Nutrition, 20(2), 50-61.

https://doi.org/10.1080/16070658.2007.11734124

Çakıroğlu, F.P., Uçar, A. (2008). Employees' perception of hygiene in the catering industry in Ankara (Turkey). Food Control, 19(1), 9-15.

https://doi.org/10.1016/j.foodcont.2007.01.001

Choi, J. H., Rajagopal, L. (2013). Food allergy knowledge, attitudes, practices, and training of foodservice workers at a university foodservice operation in the Midwestern United States. Food Control, 31(2), 474-481.

https://doi.org/10.1016/j.foodcont.2012.10.023

CDC (The Centers for Disease Control and Prevention of the USA), (2018). Foodborne Illnesses and Germs, available at: https://www.cdc.gov/foodsafety/foodborne-germs.html/ (accessed 12 December 2018).

DeBess, E.E., Pippert, E., Angulo, F.J., Cieslak, P.R. (2009). Food handler assessment in Oregon. Foodborne Pathogens and Disease, 6(3), 329-335.

https://doi.org/10.1089/fpd.2008.0102

Doménech-Sánchez, A., Laso, E., Pérez, M.J., Berrocal, C.I. (2011). Microbiological levels of randomly selected food contact surfaces in hotels located in Spain during 2007-2009. Foodborne Pathogens and Disease, 8(9), 1025-1029.

https://doi.org/10.1089/fpd.2011.0856

Dupuis, R., Meisel, Z., Grande, D., Strupp, E., Kounaves, S., Graves, A., Frasso, R., Cannuscio, C.C. (2016). Food allergy management among restaurant workers in a large US city. Food Control, 63, 147-157.

https://doi.org/10.1016/j.foodcont.2015.11.026

EAACI (The European Academy of Allergy and Clinical Immunology) (2017). available at: https://www.foodsmatter.com/allergy_intolerance/miscellaneous/research/allergy statistics.02.11.html\#tophttps://www.foodsmatter.com/allergy intolerance/miscellaneous/research/allergy_statistics.02.11.html\#top/ (access 12 September 2018).

Egan, M.B., Raats, M.M., Grubb, S.M., Eves, A., Lumbers, M.L., Dean, M.S., Adams, M.R. (2007). A review of food safety and food hygiene training studies in the commercial sector. Food Control, 18(10), 1180-1190.

https://doi.org/10.1016/j.foodcont.2006.08.001

ECDC (European Food Safety Authority and European Centre for Disease Prevention and Control) (2017). EU summary report on trends and sources of zoonoses, zoonotic agents and food-borne outbreaks in 2016.

https://doi.org/10.2903/j.efsa.2017.5077

FARE (Food Allergy Research and Education) (2017). Facts and statistics, available at: https://www.foodallergy.org/life-with-food-allergies/food-allergy-101/factsand-statistics (access 12 July 2018).

Giritlioglu, I., Batman, O., Tetik, N. (2011). The knowledge and practice of food safety and hygiene of cookery students in Turkey. Food Control, 22(6), 838-842.

https://doi.org/10.1016/j.foodcont.2010.09.016

Gomes-Neves, E., Araújo, A.C., Ramos, E., Cardoso, C.S. (2007). Food handling: Comparative analysis of general knowledge and practice in three relevant groups in Portugal. Food Control, 18(6), 707-712.

https://doi.org/10.1016/j.foodcont.2006.03.005

Jianu, C., Chiş, C. (2012). Study on the hygiene knowledge of food handlers working in small and medium-sized companies in western Romania. Food Control, 26(1), 151-156. https://doi.org/10.1016/j.foodcont.2012.01.023 
Kunadu, A.P.H., Ofosu, D.B., Aboagye, E., Tano-Debrah, K. (2016). Food safety knowledge, attitudes and self-reported practices of food handlers in institutional foodservice in Accra, Ghana. Food Control, 69, 324-330.

https://doi.org/10.1016/j.foodcont.2016.05.011

Martins, R.B., Hogg, T., Otero, J.G. (2012). Food handlers' knowledge on food hygiene: The case of a catering company in Portugal. Food Control, 23(1), 184-190.

https://doi.org/10.1016/j.foodcont.2011.07.008

Mullan, B.A., Wong, C. Kothe, E.J. (2013). Predicting adolescents' safe food handling using an extended theory of planned behavior. Food Control, 31(2), 454-460.

https://doi.org/10.1016/j.foodcont.2012.10.027

Nee, S.O., Sani, N.A. (2011). Assessment of knowledge, attitudes and practices (KAP) among food handlers at residential colleges and canteen regarding food safety. Sains Malaysiana, 40(4), 403-410.

Osaili, T.M., Al-Nabulsi, A.A., Krasneh, H.D.A. (2018). Food safety knowledge among foodservice staff at the universities in Jordan. Food Control, 89, 167-176.

https://doi.org/10.1016/j.foodcont.2018.02.011

Osaili, T.M., Obeidat, BA., Hajeer, W.A., Al-Nabulsi, A.A. (2017). Food safety knowledge among food service staff in hospitals in Jordan. Food Control, 78, 279-285. https://doi.org/10.1016/j.foodcont.2017.02.057

Osaili, T.M., Obeidat, B.A., Jamous, D.O.A., Bawadi, H.A. (2011). Food safety knowledge and practices among college female students in north of Jordan. Food Control, 22(2), 269-276.

https://doi.org/10.1016/j.foodcont.2010.07.009

Sanlier, N., Cömert, M., Durlu-Özkaya, F. (2010). Hygiene perception: Condition of hotel kitchen staffs in Ankara, Turkey. Journal of Food Safety, 30(2), 415-431.

https://doi.org/10.1111/j.1745-4565.2010.00216.x

Santos, J.R.A. (1999). Cronbach's alpha: A tool for assessing the reliability of scales. Journal of Extension, 37(2), 1-5.

Shafie, A.A., Azman, A.W. (2015). Assessment of knowledge, attitude and practice of food allergies among food handlers in the state of Penang, Malaysia. Public Health, 129(9), 1278-1284.

https://doi.org/10.1016/j.puhe.2015.03.016
Smigic, N., Djekic, I., Martins, M.L., Rocha, A., Sidiropoulou, N., Kalogianni, E.P. (2016). The level of food safety knowledge in food establishments in three European countries. Food Control, 63, 187-194.

https://doi.org/10.1016/j.foodcont.2015.11.017

Soares, L.S., Almeida, R.C., Cerqueira, E.S., Carvalho, J.S., Nunes, I.L. (2012). Knowledge, attitudes and practices in food safety and the presence of coagulase-positive staphylococci on hands of food handlers in the schools of Camaçari, Brazil. Food Control, 27(1), 206-213.

https://doi.org/10.1016/j.foodcont.2012.03.016

Tan, S.L., Bakar, F.A., Karim, M.SA., Lee, H.Y., Mahyudin, N.A. (2013). Hand hygiene knowledge, attitudes and practices among food handlers at primary schools in Hulu Langat district, Selangor (Malaysia). Food Control, 34(2), 428-435. https://doi.org/10.1016/j.foodcont.2013.04.045

Tokuç, B., Ekuklu, G., Berberoğlu, U., Bilge, E., Dedeler, H. (2009). Knowledge, attitudes and self-reported practices of food service staff regarding food hygiene in Edirne, Turkey. Food Control, 20(6), 565-568.

https://doi.org/10.1016/j.foodcont.2008.08.013

Todd, E.C., Greig, J.D., Bartleson, C.A., Michaels, B.S. (2007). Outbreaks where food workers have been implicated in the spread of foodborne disease. Part 2. Description of outbreaks by size, severity, and settings. Journal of Food Protection, 70(8), 1975-1993.

https://doi.org/10.4315/0362-028X-70.8.1975

Todd, E.C., Greig, J.D., Bartleson, C.A., Michaels, B.S. (2008). Outbreaks where food workers have been implicated in the spread of foodborne disease. Part 5. Sources of contamination and pathogen excretion from infected persons. Journal of Food Protection, 71(12), 2582-2595.

https://doi.org/10.4315/0362-028X-71.12.2582

Ulusoy, B., Çolakoğlu, N. (2015). A survey on determination of HACCP knowledge of food handlers in Istanbul food businesses. Acta Alimentaria, 44(3), 342-348.

https://doi.org/10.1556/AAlim.2014.0011

USDA (The United States Department of Agriculture), (2017). Danger Zone $\left(40^{\circ} \mathrm{F}-140^{\circ} \mathrm{F}\right)$, available at: https://www.fsis.usda.gov/shared/PDF/Danger_Zone.pdf (access 12 October 2018). 
Walker, E., Pritchard, C., Forsythe, S. (2003). Food handlers' hygiene knowledge in small food businesses. Food Control, 14(5), 339-343.

https://doi.org/10.1016/S0956-7135(02)00101-9
Webb, M., Morancie, A. (2015). Food safety knowledge of foodservice workers at a university campus by education level, experience, and food safety training. Food Control, 50, 259-264.

https://doi.org/10.1016/j.foodcont.2014.09.002 